\title{
Biodiesel Production from a Mixture of Vegetable Oils Using Marble Slurry Derived Heterogeneous Catalyst
}

\author{
Jharna Gupta and Madhu Agarwal* \\ Department of Chemical Engineering, Malaviya National Institute of Technology, India
}

Submission: March 09, 2017; Published: May 30, 2017

"Corresponding author: Madhu Agarwal, Department of Chemical Engineering, Malaviya National Institute of Technology Jaipur-302017, India, Email: magarwal.chem@mnit.ac.in

\begin{abstract}
The catalytic activity of marble slurry derived calcined marble slurry and Hydroxyaptite (HAP) as heterogeneous catalyst has been studied for biodiesel synthesis. The developed catalysts characterized by the XRD and FTIR. Experimental results showed that biodiesel yield has been increased from $91 \%$ to $94 \%$ using calcined marble slurry and HAP as solid base catalyst respectively under reaction parameters such as reaction temperature $65^{\circ} \mathrm{C}$, reaction time $3 \mathrm{hr}$, methanol to oil molar ratio $12: 1$ and catalyst concentration $4 \mathrm{wt} \%$. The solid base catalyst developed from marble slurry i.e. HAP shows superior catalytic activity for the trans esterification reaction of mixture of oils, which proposed that this waste could be possibly used as solid heterogeneous catalyst in biodiesel synthesis from mixture of edible and non edible oils.
\end{abstract}

Keywords: Biodiesel; Mixture of oils; Heterogeneous catalyst; Trans esterification

Abbreviations: FAME: Fatty Acid Methyl Ester; RSPCB: Rajasthan State Pollution Control Board; XRD: X-Ray Diffraction; MS: Marble Slurry; HAP: Hydroxyaptite; CMS: Calcined Marble Slurry

\section{Introduction}

Biodiesel can be an alternative fuel source for energy production. The main advantages of biodiesel as an alternative fuel are its renewability, biodegradability, nontoxic nature, and blending capacity with other energy sources $[1,2]$. Biodiesel is also known as fatty acid methyl ester (FAME) obtained by trans esterification reaction of methanol and vegetable oil in the presence of suitable homogeneous or heterogeneous catalyst [3]. Commonly used homogeneous catalysts are $\mathrm{NaOH}, \mathrm{KOH}$ and $\mathrm{CH}_{3} \mathrm{ONa}$ which have high catalytic activity, but it is also difficult to separate, purify and reuse them after the reaction [4]. Till now various heterogeneous alkali catalysts such as Zeolite, alkali earth metal oxides, $\mathrm{KF} / \mathrm{YAl}_{2} \mathrm{O}_{3}$ and sodium aluminate etc. have been developed for biodiesel production [5-11]. Recently only selective heterogeneous catalysts are utilized in the industry due to the high expense in catalyst synthesis. So the good alternative to reduce the overall biodiesel production cost is the utilization of waste material as a heterogeneous catalyst.

Different kinds of wastes have been explored as catalyst such as marble slurry Dolomites and waste shells such as waste egg shell, oyster shell, and scallop shell, bivalve clam shells and bones [12-19]. Among them, $\mathrm{CaO}$ is one of widely-used catalysts due to its highly availability in nature, low cost and high activity. In literature, $87.28 \%$ and $91.87 \%$ of biodiesel yield were reported using snail shell and dolomite as heterogeneous catalyst respectively under optimized conditions [20-21] also found $88 \%$ of biodiesel yield by heterogeneous catalyst developed from waste marble.

Among these wastes, marble slurry is a natural calcium carbonate source found in several areas of the world such as India, USA, Belgium, France, Spain, Sweden, and Greece. In marble processing plant, $20-30 \%$ marble blocks generates marble dust after cutting process which cannot be disposed of in the residential area. Storage of these wastes is impossible; hence marble wastes constitute an environmental Pollutant. Rajasthan State Pollution Control Board (RSPCB) proposed a project of two plants at Udaipur to recycle waste marble slurry. So the biodiesel production from marble slurry derived heterogeneous catalyst has been explored in our study. The purpose of the research was to prepare a highly basic heterogeneous catalyst derived from marble slurry for biodiesel production from a mixture of oils. Catalyst characterization has done by XRD, FTIR and Hammett titration method. 


\section{Experimental Work}

\section{Materials}

Natural marble slurry was obtained from Jaipur, Rajasthan, India. Linseed oil, palm oil, thumba oil and Karanja oil were brought from the local market. AR grade methanol with $99.9 \%$ purity and Potassium dihydrogen orthophosphate $\left(\mathrm{KH}_{2} \mathrm{PO}_{4}\right)$ from Merck limited, Mumbai India was used in this study.

\section{Quality analysis of mixture of oil}

The physicochemical properties of optimized mixture of oil were measured which has been shown in (Table 1).

Table 1: Properties of mixture of oils.

\begin{tabular}{|c|c|}
\hline Properties & Measured Value \\
\hline Color & Burnt Brown \\
\hline Acid value (mg of $\mathrm{KOH} / \mathrm{gm}$ of oil) & 15.68 \\
\hline FFA $(\%)$ & 7.84 \\
\hline Density $(\mathrm{gm} / \mathrm{ml})$ & 0.85 \\
\hline Kinematic viscosity at $40^{\circ} \mathrm{C}$ (Cst) & 33 \\
\hline $\begin{array}{l}\text { Saponification value (mg of } \mathrm{KOH} / \\
\text { gm of oil) }\end{array}$ & 196.3 \\
\hline Molecular weight (gm/mol) & 931.6 \\
\hline $\begin{array}{l}\text { Ester value (mg of } \mathrm{KOH} / \mathrm{gm} \text { of } \\
\text { oil) }\end{array}$ & 180.7 \\
\hline$\%$ glycerin & 9.9 \\
\hline
\end{tabular}

\section{Catalyst preparation}

The marble slurry (MS) sample was collected from marble shop of Jaipur, Rajasthan. The marble slurry was rinsed with distilled water several times for removing dust and then dried in oven at $120{ }^{\circ} \mathrm{C}$ for $10 \mathrm{~h}$. After drying, marble slurry was calcined at temperature of $850^{\circ} \mathrm{C}$ for $3 \mathrm{hr}$ in muffle furnace. The Calcined material was then cooled down to room temperature in a desicator and then used for biodiesel synthesis.

The synthesized basic heterogeneous catalyst form marble slurry powder i.e. Hydroxyaptite was prepared by wet method as described in literature. Twenty grams of dried marble slurry powder was dissolved in $800 \mathrm{ml}$ of $1 \mathrm{M}$ Potassium dihydrogen orthophosphate $\left(\mathrm{KH}_{2} \mathrm{PO}_{4}\right)$. The preperared solution was then heated in microwave oven for 20 minutes and resulted as Hydroxyaptite (HAP) powder. HAP powder was cleaned with distilled water and was dried by microwave for 15 minutes followed by $5 \mathrm{~h}$ calcination at $850{ }^{\circ} \mathrm{C}$. Untreated marble slurry and resulted catalysts into powder form as shown in (Figure 1).

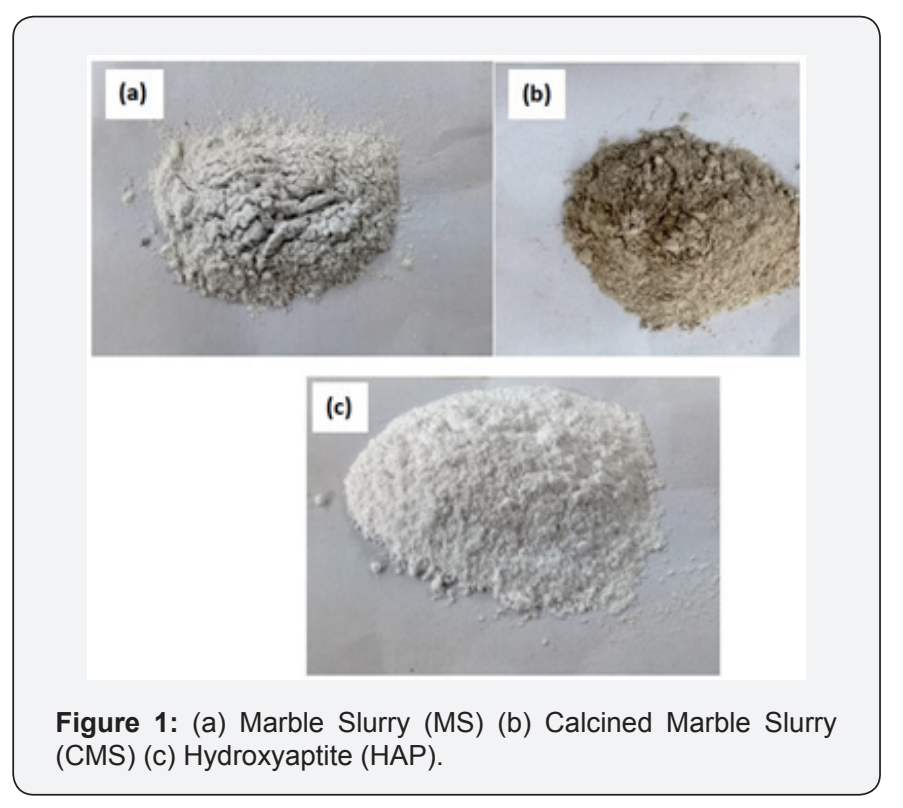

\section{Catalyst characterization}

X-ray diffraction (XRD) analysis was done using X-Pert Pro powder analytical instrument equipped with $\mathrm{Cu}$ anode under the following conditions: tube voltage of $40 \mathrm{kV}$, a tube current of $40 \mathrm{~mA}$ and the sample were scanned in the range of $2 \theta=10$ $90{ }^{\circ} \mathrm{C}$. The FTIR (Fourier Transform Infrared Spectroscopy) spectrum of the sample was obtained on FTIR spectrometer (Perkin Elmer spectra two) in the range of $400-4500 \mathrm{~cm}^{-1}$ by $\mathrm{KBr}$ pellet. Catalytic basicity was also examined by Hammet method [22-27].

\section{Biodiesel production method}

Various mixtures containing different proportions of four oils with high acid fatty were chosen for biodiesel production through two step trans esterification process at similar operating conditions (temperature $65{ }^{\circ} \mathrm{C}$, time $60 \mathrm{~min}, 6: 1$ methanol to oil molar ratio, $\mathrm{KOH}$ catalyst loading $1 \mathrm{gm} / 100 \mathrm{cc}$ ). The blends producing highest yield and better biodiesel properties were selected for further studies.

In the first step, the esterification reaction was carried out to reduce FFA at $60-70{ }^{\circ} \mathrm{C}$. The experimental set up includes $250 \mathrm{ml}$ two necks round bottom flask equipped with a reflux condenser, temperature controller and magnetic stirrer. $100 \mathrm{ml}$ of oil mixture was preheated to the set temperatures $\left(60^{\circ} \mathrm{C}\right)$ before starting the reaction. A fixed amount $(1-2 \mathrm{ml})$ of $\mathrm{H}_{2} \mathrm{SO}_{4}$ was mixed to reaction mixture consisting of methanol and oil in 6:1 molar ratio. After completion of 2 hour reaction time, the product mixture was transferred to the separating funnel for separation of phases. The upper phase consisting of esterified sample was separated, stored for further trans esterification reaction.

In last, the trans esterification reaction was done using developed heterogeneous catalysts. The $100 \mathrm{ml}$ of esterified oil mixture was preheated and added into the flask containing 
methanol and catalyst under vigorous stirring. The trans esterification reaction was done $65{ }^{\circ} \mathrm{C}$ with a reaction time $(3$ hours),12:1 methanol to oil molar ratio for $3 \mathrm{hrs}$. After the reaction, the reaction product was transferred to the separating funnel for separation of phases. The solid base catalyst was separated from the reaction mixture via centrifugation at 5000rpm for $20 \mathrm{~min}$. Glycerol was then separated using a separating funnel, and the excessive amount of methanol from FAME was recovered under reduced pressure in a rotary evaporator. The FAME thus obtained was stored for further characterization. The biodiesel yield (\%) was calculated as follows:

Biodiesel yield $(\%)=($ volume of biodiesel $(\mathrm{ml})) /($ volume of oil( ml))x100 (1)

\section{Results and Discussion}

\section{Catalyst characterization}

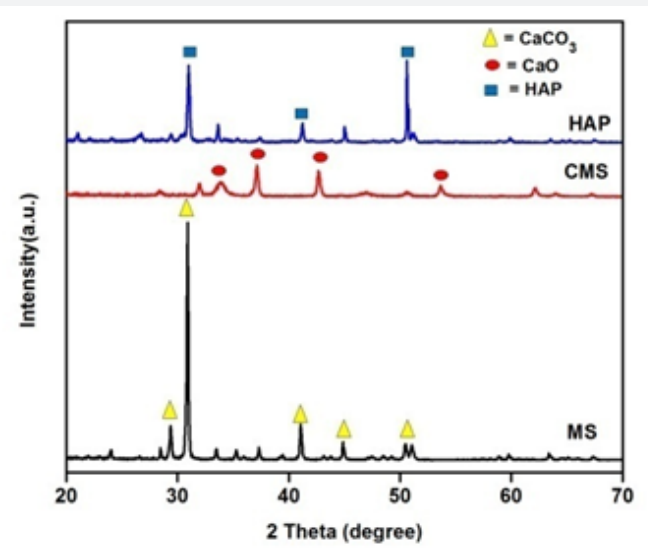

Figure 2: XRD pattern for catalyst.

XRD analysis: To investigate the structure and crystallinity of the catalyst, the X-ray diffraction analysis was done as shown in (Figure 2) shows the XRD result of marble slurry (MS), calcined Marble slurry (CMS) and Hydroxyaptite powder (HAP). The crystallinity of all the samples was analyzed by XRD. The source material i.e. MS showed major diffraction peaks at $29.38^{\circ}, 30.92^{\circ}$ and $41.06^{\circ}$ which is characteristic of $\mathrm{CaCO} 3$ (marble slurry) and after calcination, the reflection arising from marble slurry were

Table 2: Quality analysis of Biodiesel. lost, coincident with the appearance of new crystalline phase that can be assigned to highly crystalline $\mathrm{CaO}\left(33.92^{\circ}, 37.11^{\circ}\right.$, and $42.65^{\circ}$ ) as described in literature [28,29]. XRD patterns of HAP shows the two highest peaks at $31.02^{\circ}$ and $50.61^{\circ}$ which is characteristics of HAP and closed to HAP standard compared with literature [30-31]. These result indicated that the marble slurry had been successfully synthesized into HAP.

FTIR analysis: FTIR analysis of marble slurry (uncalcined and calcined) and HAP powder was performed as shown in (Figure 3). Two bands around $878 \mathrm{~cm}^{-1}$ and $1435 \mathrm{~cm}^{-1}$ are confirm the $\mathrm{C}-\mathrm{O}$ stretching and bending modes of $\mathrm{CaCO}_{3}$ as shown in (Figure 3). After calcinations at $8500 \mathrm{C}$ the intensity of these bands decreases due to thermal decomposition of $\mathrm{CaCO}_{3}$ and formed $\mathrm{CaO}$ and $\mathrm{Ca}(\mathrm{OH})_{2}$. One sharp band appears $3642 \mathrm{~cm}^{-1}$ due to the formation of basic $\mathrm{OH}$ groups attached to the calcium atoms as shown in (Figure 3). Hydroxyl stretch is observed at $3643 \mathrm{~cm}^{-1}$ in the spectra of Hydroxyaptite as shown in (Figure 3 ). There were also bands at $103.04 \mathrm{~cm}^{-1}$ and $1420 \mathrm{~cm}^{-1}$, which were assigned to the phosphate group and the carbonate group $\left(\mathrm{CO}_{3}{ }^{2}-\right)$.

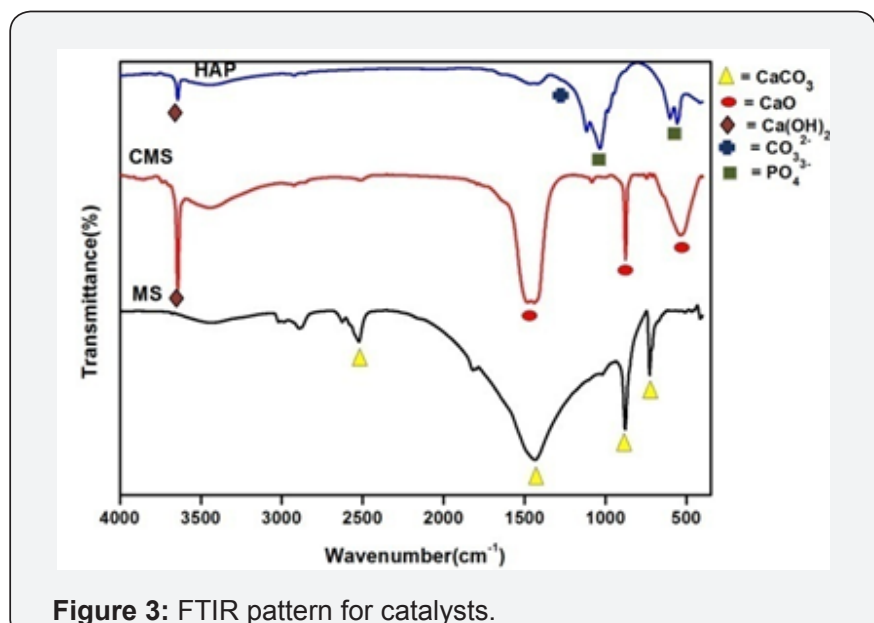

\section{Biodiesel characterization}

The characteristics of oil mixture biodiesel were measured and compared with ASTM D6751 Standard and found within the prescribed limit See (Table 2).

\begin{tabular}{|c|c|c|c|c|}
\hline Properties & Unit & Biodiesel from CMS & Biodiesel from HAP & ASTM Standard \\
\hline Density & $(\mathrm{gm} / \mathrm{ml})$ & 0.87 & 0.88 & $0.86-0.90$ \\
\hline Kinematic viscosity & at $40^{\circ} \mathrm{C}(\mathrm{Cst})$ & 4.98 & 5.72 & 0.9 \\
\hline Acid value & $(\mathrm{mg} \mathrm{of} \mathrm{KOH} / \mathrm{gm}$ of oil) & 0.4 & 9 & -3 to 12 \\
\hline Cloud point & ${ }^{\circ} \mathrm{C}$ & 6 & 3 & -15 to 10 \\
\hline Pour point & ${ }^{\circ} \mathrm{C}$ & -3 & 155 & $130-170$ \\
\hline Flash point & ${ }^{\circ} \mathrm{C}$ & 160 & 0.5 \\
\hline
\end{tabular}




\section{Conclusion}

The mixture of oils can be efficiently converted into biodiesel using marble slurry derived modified heterogeneous catalyst. Among both catalysts tested, HAP shows high catalytic activity with good biodiesel yield i.e. $94 \%$ in the biodiesel production form mixture of oil at the reaction conditions such as reaction time of $3 \mathrm{~h}$, methanol to oil molar ration of $12: 1$, reaction temperature of $65{ }^{\circ} \mathrm{C}$ and catalyst loading of $4 \mathrm{wt} \%$. More importantly than all of that, this catalyst is good for biodiesel production from the economic point of view, which makes waste utilization, reduces cost, saves resources, and protects the environment.

\section{References}

1. Chouhan SAP, Sarma AK (2011) Modern heterogeneous catalysts for biodiesel production: a comprehensive review. Renewable and Sustainable Energy Reviews 15: 4378-4399.

2. Gupta J, Agarwal M, Dalai AK (2016) Optimization of biodiesel production from mixture of edible and nonedible vegetable oils. Biocatalysis and Agricultural Biotechnology 8: 112-120.

3. Agarwal M, Chauhan G, Chaurasia SP, Singh K (2012) Study of catalytic behavior of $\mathrm{KOH}$ as homogeneous and heterogeneous catalyst for biodiesel production. Journal of the Taiwan Institute of Chemical Engineers 43(1): 89-94.

4. Jharna Gupta, Madhu Agarwal (2015) Biodiesel Production by Heterogeneous Catalyst: A Review. ISST journal of Applied Chemistry 6(1): 53-60.

5. Gupta J, Agarwal M (2016) Preparation and characterization of highly active solid base catalyst from snail shell for biodiesel production. Biofuels 1-10.

6. Volli V, Purkait MK (2015) Selective preparation of zeolite X and A from flyash and its use as catalyst for biodiesel production. Journal of hazardous materials 297: 101-111.

7. Lee HV, Taufiq-Yap YH (2015) Optimization study of binary metal oxides catalyzed transesterification system for biodiesel production. Process Safety and Environmental Protection 94: 430-440.

8. Lijing G, Songcheng W, Wei X, Guomin X (2015) Biodiesel production from palm oil over monolithic KF/ $\gamma$-Al 203 /honeycomb ceramic catalyst. Applied Energy 146: 196-201.

9. Shahraki H, Entezari MH, Goharshadi EK (2015) Sono-synthesis of biodiesel from soybean oil by KF/ $\gamma$-Al 203 as a nano-solidbasecatalyst. Ultrasonics sono chem 23: 266-274.

10. Tao W, Yu P, Wang S, Luo Y (2009) Application of sodium aluminate as a heterogeneous base catalyst for biodiesel production from soybean oil. Energy \& Fuels 23(2): 1089-1092.

11. Balakrishnan K, Olutoye MA, Hameed BH (2013) Synthesis of methyl esters from waste cooking oil using construction waste material as solid base catalyst. Bioresour technol 128: 788-791.

12. Correia LM, Campelo NS, Denise SN, Celio LC, Juan AC, et al. (2015) Characterization and application of dolomite as catalytic precursor for canola and sunflower oils for biodiesel production. Chemical Engineering Journal 269: 35-43.

13. Niju S, Meera KM, Begum S, Anantharaman N (2014) Modification of egg shell and its application in biodiesel production. Journal of Saudi Chemical Society 18(5): 702-706.

14. Danlin Z, Zhang Q Shiyuan C, Shenglan Liu, Yang C, et al. (2015) Preparation and characterization of a strong solid base from waste egg shell for biodiesel production. Journal of Environmental Chemical Engineering 3(1): 560-564.

15. Jairam S, Kolar P, Sharma-Shivappa R, Osborne JA, Davis JP, et al. (2012) KI-impregnated oyster shell as a solid catalyst for soybean oil transesterification. Bio resource technol 104: 329-335.

16. Sirisomboonchai S, Maidinamu A, Guoqing G, Chanatip S, Shawket A, et al. (2015) Biodiesel production from waste cooking oil using calcined scallop shell as catalyst. Energy Conversion and Management 95: 242247.

17. Niju S, KM Meera Sheriffa Begum, Anantharaman N (2014) Enhancement of biodiesel synthesis over highly active $\mathrm{CaO}$ derived from natural white bivalve clam shell. Arabian Journal of Chemistry 9(5): 633-639.

18. Farooq MD, Ramli A, Naeem A (2015) Biodiesel production from low FFA waste cooking oil using heterogeneous catalyst derived from chicken bones. Renewable Energy 76: 362-368.

19. Birla A, Singh B, Upadhyay SN, Sharma YC (2012) Kinetics studies of synthesis of biodiesel from waste frying oil using a heterogeneous catalyst derived from snail shell. Bioresource technol 106: 95-100.

20. Ilgen 0 (2011) Dolomite as a heterogeneous catalyst for transesterification of canola oil. Fuel Processing Technology 92(3): 452-455.

21. Gencel O, Cengiz O, Fuat K, Ertugrul E, Gonzalo M, et al. (2012) Properties of concrete paving blocks made with waste marble. Journal of Cleaner Production 21(1): 62-70.

22. EAI (Catalyzing Cleantech and sustainability) (2014) Rajasthan Pollution Board Proposes Recycle of Marble Slurry to Minimize Hazards. EAI, India.

23. Itokazu M, Wenyi Y, Takaaki A, Akira O, Naoki K (1998) Synthesis of antibiotic-loaded interporous hydroxyapatite blocks by vacuum method and in vitro drug release testing. Biomaterials 19(7): 817-819.

24. Sadat-Shojai M, Atai M, Nodehi A (2013) Method for production of biocompatible nanoparticles containing dental adhesive. US Patent $8,357,732$.

25.Zahouily M, Abrouki Y, Bahlaouan B, Rayadh A, Sebti S (2003) Hydroxyapatite: new efficient catalyst for the Michael addition. Catalysis Communcations 4(10): 521-524.

26. Sugiyama S, Minami T, Hayashi H, Tanaka M, Shigemoto N, et al. (1996) Partial oxidation of methane to carbon oxides and hydrogen on hydroxyapatite: enhanced selectivity to carbon monoxide with tetrachloromethane. Energy \& Fuel 10(3): 828-830.

27. Zeng D, Qi Z, Shiyuan C, Shenglan Liu, Yang C, et al. (2015) Preparation and characterization of a strong solid base from waste eggshell for biodiesel production. Journal of Environmental Chemical Engineering 3(1): 560-564.

28. Wei Z, Chunli Xu, Baoxin Li (2009) Application of waste eggshell as low-cost solid catalyst for biodiesel production. Bioresource technology 100(11): 2883-2885.

29. Chen G, Rui S, Jiafu S, Changye L, Bebei Y (2015) Biodiesel production from palm oil using active and stable $\mathrm{K}$ doped hydroxyapatite catalysts. Energy Conversion and Management 98: 463-469.

30. Pujiyanto E, Laksono PW, Triyono J (2014) Synthesis and characterization of hydroxyapatite powder from natural gypsum rock. Advanced Materials Research 893: 56-59.

31. Suryaputra W, Indra W, Nani I, Suryadi I (2013) Waste capiz (Amusium cristatum) shell as a new heterogeneous catalyst for biodiesel production. Renewable energy 50: 795-799. 
This work is licensed under Creative Commons Attribution 4.0 License DOI: 10.19080/CTBEB.2017.05.5556501
Your next submission with Juniper Publishers will reach you the below assets

- Quality Editorial service

- Swift Peer Review

- Reprints availability

- E-prints Service

- Manuscript Podcast for convenient understanding

- Global attainment for your research

- Manuscript accessibility in different formats

( Pdf, E-pub, Full Text, Audio)

- Unceasing customer service

Track the below URL for one-step submission https://juniperpublishers.com/online-submission.php 